Shepard, Alexandra. Accounting for Oneself. Worth, Status, and the Social Order in Early Modern England. Oxford University Press, London 20 I 5. xv, 357 pp. $£ 65.00$.

Accounting for Oneself offers a unique perspective: a view of early modern English society as seen from the bottom, in which men and women explored, in their own words, albeit in the briefest of terms, the relationships that pertained between their wealth, occupation, and social identity. Instead of the abstract pontifications of the elite on social structure, we hear personal descriptions such as that of the Kentish widow who stated in 1609 that she maintained herself by fishing, "keepinge certayne netts for that purpose" (p. I 54), or of the wife of a blacksmith who claimed in 1646 that "she cannot tell what her husband is worth (by reason she knowes not what debtes hee owes) but beleeves he is worth five powndes of lawfull English money his debtes payd" (p. 6r).

This book is based on just over $\mathrm{I}_{3}, 600$ such statements, given in response to questions posed to witnesses about their worth from the mid-sixteenth century, when they began to be asked regularly, to the mid-eighteenth century, by which time their insistence had declined and the answers had altered in focus. These answers were recorded by such courts as operated civil-law procedure and produced written depositions as part of their formal record of proceedings - mainly ecclesiastical courts - in which as many as one in seven of the adult population might have appeared at some stage in their lives. Forged in the period's heated engagement with litigious dispute, the mini-biographies that deponents offered were, Shepard argues, "part of broader strategies for testing witness credibility [...] criteria with which early modern people judged and experienced social differentiation, not just in court but in the vibrant social world beyond" (p. 2).

She explores these strategies for self-representation in three main sections: "Wealth and Poverty", which investigates ways of "Calculating Credit" and "Quantifying Status", as well as the deployment of the boundaries of poverty, based on the value given to material possessions; "Maintenance", in which she considers the rhetorics of personal support in income and working practices, acknowledging dependence on others, and occupational identities; and the shorter "Changing Currency of Credit", in which she addresses the changes taking place into the eighteenth century in the strategies she identifies in the previous sections. These changes centre on the shifting nature of the relationship between individuals, their goods and their employment, and men's and women's evolving opinions about external interest in their property. By the end of the book, in a period whose attitude towards material goods had been fundamentally altered by the Civil War and an increase in forced loans, among other factors, "The honour of protecting one's property from unnecessary incursions [by the state] coexisted uneasily with the honour associated with being numbered among the 'subsidy men' and therefore of good credit” (p. 29I). Work, too, was differently assessed as a form of maintenance, after "a gradual tipping of the balance between assumptions that assets dictated activity and expectations that activities produced assets" (p. 3 IO).

One of the key findings of the different perspective offered here is that, in the period on which the study mainly focuses, it was goods that were reliable - money could be seen as suspect, whereas moveables' tangibility was reliably transparent. Shepard argues that "attaching value to one's own and other people's possessions was a routine part of quotidian social relations" (p. I I2), and that it was on that process of appraisal that "social estimation was founded" (p. 3 I). The full implications of these findings for our understanding of the function of early modern material culture are immense. 
The variables that Shepard considers in this powerful narrative, of geography, status, and gender, are harder to articulate but crammed with interesting insight. For example, the striking divergence in levels of wealth claimed, between yeomen on the one hand, and husbandmen, most tradespeople, artisans, and labourers on the other. Shepard compares the "socially distinctive trajectory of yeomen" (p. 77) with the wealth claimed by the gentry, showing the median value of the assets of the two groups coinciding at $£_{\mathrm{I}} \mathrm{O}$. But she then qualifies this as a southern phenomenon, and shows how significant the age at which these statements were made could be: while yeomen identified the sum of $£_{100}$ at middle age, gentlemen claimed it from the age of twenty-five.

The variable that might strike readers as offering the most valuable new evidence is that of gender. Almost a quarter of the dataset is made up of the statements of female witnesses, whose representation increased with time and was more pronounced in the south. Their responses to the questions about their worth paint an often surprisingly positive picture of their economic agency. It appears, for instance, that it was during marriage, rather than widowhood, that "women undertook more varied and independent forms of work, despite the strictures of coverture” (p. 223), and their management of assets within the domestic economy formed an important aspect of thinking about the family's substance. As a result, Shepard posits the terms "wife" and "widow" as status and occupational categories, ones whose full resonance has been lost to us through our lack of knowledge about contemporary attitudes towards work and worth. Here, and elsewhere, the book offers valuable evidence to retune our ears to such familiar early modern terms - including fascinating insights into "painstaking", for instance, last used in I669, at which point it was overtaken by the language of industry.

Throughout Accounting for Oneself, pains are taken to key the findings from this patchwork of pieces of evidence for local thought and practice into a national framework of ideas. Shepard points out, for instance, that "no more than four or five values constituted well over half of witnesses' monetary estimates of their net moveable wealth" (p. 94) and she traces the significance of these sums in a range of other legal discourses around taxation and enfranchisement which explains their meaning for deponents - 4os, for instance, had been meaningful as an economic threshold as far back as the sumptuary legislation of $\mathrm{I}_{3} 63$. Reinstating the histories of these significant wealth levels makes it clear just how complicated the relationship between individual and group identities was in this period, and Shepard uses her findings to complicate Henry French's thesis about the local brokering of middling status.

As this latter example indicates, this is a book that is fully keyed into some of the most important recent narratives of early modern economics, identity politics, and working practice. It offers frequent nuance and qualification to Muldrew's picture of the nation's changing economy, and it calls into question elements of Jan de Vries's arguments about women's "industriousness" in the long eighteenth century, arguing that it is "an optical illusion generated by the growing visibility of women's work linked to specialization (particularly in urban contexts) rather than simply a function of increased market orientation" (p. 30). In the first two sections in particular, these arguments are firmly based in the detail of the source material and they significantly advance our understanding through the author's analysis of witnesses' distinctive perspective. Towards the end of the book, those lives seem to fade a little and the language is vaguer and the assertions more strident.

As lives fade out, things come partially into focus. But they come late in two senses in Accounting for Oneself: discussed only at the very end of the book, they are mainly seen through the lens of a historiography of consumption that privileges the eighteenth century. 
If it is in the previous two centuries that their materiality was so significant in the construction of identity, then how things were circulating in that earlier period seems a pressing question. Information on these things, and on the processes of assessment and the domestic knowledge and interactions on which they were based, is buried slightly deeper within the meat of the court depositions themselves of course. While unpicking it would have been a different and even larger project than the one this book represents, a few more developed case studies would have been very welcome. When we read that the widow Joan Ballard had two pairs of sheets, an old chest, and an old rotten bed "so lowsy" that it was "cast out of dores being not worth any thing" when she died (p. I 24), but that she had asked the wife of one of the men into whose care she had entrusted her daughters to keep the sheets for them when they came of age, a moving world of why and how goods conferred identity opens up. More such stories will be needed to tell the full tale of a society whose worth was represented by its possessions. In the meantime, this book lays a very significant, much-needed, and most welcome foundation of quantitative and qualitative data for such an enterprise.

\section{Catherine Richardson}

University of Kent, Rutherford College Canterbury, Kent $\mathrm{CT}_{2}{ }_{7} \mathrm{NX}$, UK

E-mail: C.T.Richardson@kent.ac.uk doi: $10.1017 /$ S0020859017000098

Unkovski-korica, Vladimir. The Economic Struggle for Power in Tito's Yugoslavia. From World War II to Non-Alignment. I.B. Tauris, London [etc.], 2016. x, 294 pp. Ill. \$i 10, 269.

With horrifying images of wars in former Yugoslavia still featured prominently in the world media, the mid-I990s saw a great demand for academic studies trying to make sense of the disorder by tracing legacies of ethnic rivalries, nationalist dissidence, and authoritarian politics in the Balkans. One important book stood out from this trend. Susan Woodward's Socialist Unemployment ${ }^{\mathrm{I}}$ focused on Yugoslavia's peculiar geopolitical position and labour policies. It explained the country's collapse by embedding the workers' self-management system into a broader context of world market pressures and persistent unemployment, circumstances that exacerbated regional inequalities and contributed to national tensions. Originally met with guarded reactions for its alleged oversight of local agency and for the dense style with which it was written, years later this offbeat research found a receptive readership in the new generation of left-leaning academics and activists in former Yugoslavia, eager to go beyond the "ancient hatreds" clichés and to revise the self-management experience.

The Economic Struggle for Power represents the most studious, in-depth historical research produced so far by younger scholars reassessing socialist Yugoslavia through the I990 (Princeton, NJ, 1995). 